\section{Empowering small industry of wood carving handicraft in Bangli district}

\author{
A.A.I.N. Marhaeni, Ni Nyoman Yuliarmi and \\ Nyoman Djinar Setiawina \\ Faculty of Economics and Business, University of Udayana, Bali, Indonesia
}

Wood carving handicraft

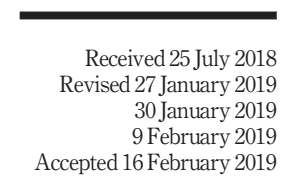

\begin{abstract}
Purpose - The purpose of this study is to analyze the influence of social capital on human capital; the effect of social capital on transaction costs; the influence of social capital, human capital and transaction costs on empowerment; the indirect effect of social capital on empowerment through human capital; and the indirect effect of social capital on empowerment through transaction costs in Bangli Regency.

Design/methodology/approach - The population in this research is all wood carving business in Bangli Regency, in all districts some 366 business units. The number of respondents surveyed were 191 business units in all sub-districts. The sampling technique used is stratified random sampling, with strata of business area. Inferential analysis is preceded by using factor analysis techniques to obtain factor scores on each latent variable, followed by path analysis to answer the research objectives.

Finding - Based on the analysis, the following conclusions are drawn: social capital has a positive and significant impact on human resources; positive social capital and significant positive to transaction costs; social capital and human resources have a positive and significant effect while transaction costs and no significant positive effect on empowerment; human resources partially mediate the influence of social capital on empowerment; and transaction costs do not act as a variable, mediating the influence of social capital on empowering small woodcraft industry in Bangli Regency.

Originality/value - This study is one of the few to investigate the role of social capital, human capital and transaction cost on empowerment of small industries, especially wood carving in Bangli District. This small woodcraft industry is famous for its uniqueness that characterizes Balinese carving ornaments. But lately, the productivity of handicrafts wood carving, especially in Bangli District, fluctuates tend to decline. Social capital, in addition to human capital and technology, also plays an important role in the production process. Social capital equals other physical capital and can increase productivity and economic efficiency. Higher social capital owned by individuals or groups can reduce transaction costs; thus economic activity can run efficiently. Social capital is the information, trust and norms of reciprocity inherent in social networks.
\end{abstract}

Keywords Social capital, Human capital, Transaction costs, Empowerment

Paper type Research paper

\section{Introduction}

Small and medium enterprises (MSMEs), including small woodcraft industry in Bali Province, which some of its products are supporting the tourism sector certainly have a very wide impact on the development of tourism. When tourism is in a stable condition, UMKM is

(C) A.A.I.N. Marhaeni, Ni Nyoman Yuliarmi and Nyoman Djinar Setiawina. Published in Asia Pacific Journal of Innovation and Entrepreneurship. Published by Emerald Publishing Limited. This article is published under the Creative Commons Attribution (CC BY 4.0) licence. Anyone may reproduce, distribute, translate and create derivative works of this article (for both commercial and noncommercial purposes), subject to full attribution to the original publication and authors. The full terms of this licence may be seen at http://creativecommons.org/licences/by/4.0/legalcode 
APJIE 13,1

also stable. If the condition of tourism decreases, then MSMEs also follow a downward trend. Problems of business actors concerning the needs of venture capital, improving the quality of human resources and the problem of weakness of marketing often weaken the empowerment of UMKM.

Competition that increasingly demands the perpetrators of SMEs to deal with competition by increasing innovation enhance creativity with product features that are more unique than the product competitors. Business performance can be demonstrated by, among other things, increased sales turnover or increased revenue. The higher the ability to increase productivity in the process of industrialization, the more business actors will be encouraged to increase revenue (Arsyad, 2001). If the technology used is modern, then the production of goods or services is more (Suparmoko, 2002). Technology can help the workforce to speed up the production process. With the help of technology, all the resources can be used optimally in the production process. Helping to increase production, so that the application of technology has a positive effect on production (Li and Liu, 2015).

Although technology can negatively impact labor absorption (Lino and Vella, 2014), the role of technology can also have a positive effect on industrial productivity, as it can improve production quality. If the industrial sector develops, it will have an impact on economic growth (Purnomo and Devi, 2008). Therefore, the government's efforts to improve the industry, including small industries, especially woodworking industries, are also encouraged to be more empowered, because they are able to absorb a relatively large number of workers.

Qualified human resources, determined by not only formal education level but also high skills gained from informal education, can also increase productivity. These formal and informal institutions can influence the behavior of someone who gives more assurance in the interaction so as to produce output such as economic performance, efficiency, growth and economic development (Kherallah and Kristen, 2001). Qualified human resources can produce quality products, which contribute significantly to the production process of an industry (Shaikh, 2012). Quality resources can increase the empowerment of the craftsmen who pursue the craft of small industries, because it can increase production, increase innovation and at the same time increase revenue.

Social capital, in addition to human capital and technology, also plays an important role in the production process. Social capital equals other physical capital and can increase productivity and economic efficiency. Higher social capital owned by individuals or groups can reduce transaction costs; thus economic activity can run efficiently. Social capital is the information, trust and norms of reciprocity inherent in social networks (Woolcock, 1998; Voydanoff, 2001). The data show that the highest production value of the wood carving industry is Gianyar Regency, but the number of wood carving business units is mostly in Bangli Regency (Department of Industry and Trade of Bali Province, 2016). The production of wood craft industry in 2011-2015 in Bangli Regency tends to fluctuate but increased in 2015. Problems such as those of raw materials are still faced by craftsmen, especially wood carving craftsmen who use special raw materials such as cempaka wood, jackfruit and "majegau," which is relatively rare. In addition, from the results of interviews with the craftsmen, there is a decrease in the order of products produced. Business activities that incur transaction costs can be minimized with a strong social capital. With the role of strong social capital from the craftsmen, by increasing cooperation, sharing information and increasing trust between craftsmen and related institutions, handicraft business can be improved. Based on the background of the problem, the purpose of this study is to analyze:

- the influence of social capital on human capital;

- the effect of social capital on transaction costs; 
- the influence of social capital, human capital and transaction costs on empowerment;

- the indirect effect of social capital through human capital on empowerment; and

- indirect effect of social capital through transaction costs on empowering the small woodcraft industry in Bangli Regency.

This study was developed from four journals: Development of empowerment variables by Miranda and Miranda (2018), social capital variables by Tran and Korflesch (2016), human capital variables by Park and Park (2018) and transaction costs variables by Yeo and Saboori-Deilami (2017).

\section{Literature review}

Empowerment energizes those concerned to be able to move independently (Sumodiningrat, 2000; Roebyantho and Padmiati, 2007). The study of empowerment was discovered Sippola (2007) aims to investigate multiculturalism in the workplace using a training method and development of empowerment-based diversity. The emergence of the concept of empowerment can be caused by the failure, especially the failure of economic development models, in tackling the problem of poverty and environmental sustainability. Expectations arise because of development alternatives that incorporate democratic values, gender equality, generational equations and adequate economic growth. Failures and expectations will be felt at the individual and community levels. Therefore, the empowerment of society should happen not only economically but also politically so that in the end the society has a bargaining position both nationally and internationally (Friedmann, 1992; Hendratmoko and Marsudi, 2010).

As a process, empowerment is focused on increasing organizational capacity or increasing group participation, whereas empowerment as a result is focused on improving the economy and access to economic resources (Luttrell et al., 2009). Empowerment can improve the ability of each individual, especially vulnerable and weak groups. Thus, they have the ability to fulfill their basic needs, have freedom, are able to access productive resources to increase income and obtain goods and services needed and can participate in development processes that can affect their lives (Suharto, 2014).

Social capital is a multiple entity that encompasses several aspects of the social structure and facilitates the specific actions of both individual and corporate actors within the structure (Coleman, 1988). From this perspective, as well as other capital, social capital is also productive, i.e. making certain achievements that cannot be achieved if its existence does not exist. Coleman's conclusion of social capital attempts to introduce the concept of social theory, in that social capital is in line with the concepts of financial capital, physical capital and human capital, but it establishes relationships among people. Social capital as an interpersonal manifestation based on the existence of togetherness, trust, honesty, network formed between each other and the existence of agreed norms, and it will create a harmonious interpersonal condition that will establish a relationship. This statement is corroborated by Cox (1995), who explains that social capital is a series of processes of interpersonal relationships supported by networks, norms and social beliefs that enable effective coordination and cooperation to achieve mutual benefits. Coleman $(1988,1990)$ also explains that the established belief of mutual interaction between the two groups is limited by the norms of relationships agreed by both parties; thus, the risk of behaving distortingly as opportunistic behavior can be eliminated. If two parties do reciprocity, not understanding each other then social capital will not be built (Adler and Kwon, 2000). Portes (1998) explains that through Bourdieu's emphasis on the emergence of different forms of capital and on the 
APJIE 13,1

final reduction of all forms of economic capital, this is defined as the accumulation of human labor. Thus, through social capital, actors can gain direct access to economic resources, they can increase cultural capital through contact with experts or individuals to make improvements or they can join institutions that deliver important values (e.g. institutional cultural capital).

Social capital in turn generates further resources that contribute to social organization of society and social networking resources. Bowles and Gintis (2002) explain that social capital generally refers to trust, caring for others, the willingness to live by referring to the norms prevailing in a community and getting sanctioned if they do not obey it. Trust is the hope that grows in a community group; norms are understandings, values, expectations and goals that are believed and run together by community groups. The network formed in the interaction is a dynamic infrastructure that can bridge communication and formal and informal interaction (Fukuyama, 2000). Social sanction given by society both individually and in groups will have an impact on their existence in society. It would be more frightening for a particular group of people to accept a social sanction than the usual legal sanctions. Research conducted by Yuliarmi et al. (2012) found that social capital had a significant effect on the role of traditional institutions (adat institutions) in SMEs studied.

Group solidarity because of mutual support, their knot, freeing the borrowers from the dependence relationship and the group pressure itself then become the bases for building a wider network (Subandi, 2007). The result of Ramli's (2010) research suggests that there is an actual correlation between social capital with poor family empowerment, meaning increasing social solidarity, trust and reciprocal relationship is followed by increasing the empowerment of poor families in terms of ability to perform family functions and creative and household harmony. Social capital is not only built individually but also lies in a growing tendency within a group to socialize as an important part of the inherent values (Hasbullah, 2006). Social capital will be strong if there is a strong capacity of existing capacity within community groups to build a number of associations including network building.

Relational social capital will have a positive effect on supplier's performance (Sukoco and Hardi, 2013). Mutual trust between buyers and suppliers will increase the effectiveness in sharing information. The mutual trust between two companies that make transactions is a strong social capital, as Collins and Hitt (2006) and Wu (2008) have pointed out. Social capital is also capable of reducing opportunistic behavior and reducing transaction costs (Dyer and Singh, 1998). Given the mutual trust that reflects social capital, it will eventually accelerate the commercialization process of a new product because the buyer has high confidence on the supplier (Adler and Kwon, 2002). Human capital is an important variable to consider for the success of a company. Human capital is also seen as an important variable if you want to know the importance of intellectual capital. Human capital is the dimension of intellectual capital based on human knowledge and experience, and it will affect the value of the enterprise by affecting other elements (Mushrel, 2014). The more experienced an individual in a company and the higher the knowledge he/she has, the more the added value of the company concerned can increase. Knowledge can also be obtained through formal and informal education through training that can be followed to improve competence. The higher the level of competence someone then there is their tendency to improve the ability to manage a company, so as to improve competitiveness. According to Brinker (2000), there are some basic characteristics that can be measured from human capital, such as training programs, experience, competence, recruitment, mentoring, learning program and individual potential. Mayo (2001) states that human capital can be divided into three dimensions of ability and potential, motivation and commitment 
innovation and learning. Humans have different abilities and potentials, hence the need to develop their ability and potential. Research conducted by Salazar-Acosta (2006), Lubis and Saputra (2015), Abedullah and Mushtaq (2007) and Adojutelegan et al. (2015) also obtained the results of research that labor has a positive and significant effect on production. Ng'ombe and Kalinda (2015), as well as research conducted by Ho et al. (2014), stated that labor is the most influential factor in production.

One of the most popular analytical tools in institutional economics is the economics of transaction costs. Excessive transaction costs incurred will increase the costs incurred in the production process. Therefore, the amount of transaction costs that arise in an economic transaction should be able to be pressured in such a way that economic activity can run efficiently. The inefficiency of an institution can be reflected in the high transaction costs. Therefore, an institution is efficient if it can reduce transaction costs as low as possible. Nort et al. (1991), Mburu (2002) and Yustika (2013) define transaction costs as the costs incurred to negotiate, measure and enforce exchanges. Transaction costs are costs incurred including search and information costs, negotiation costs and decisions or execution of contracts, including costs of supervision, coercion and execution. Transaction costs as well as production costs can also be grouped into fixed transaction costs associated with specific investments made in the preparation of institutional agreements. And, variable transaction costs relate to costs incurred based on the amount and volume of transactions. North and Wallis (1994), Mburu (2002) and Yustika (2013) considers that transaction costs arise because of the transfer of ownership or ownership rights. Transaction costs are the costs of land, labor, capital and entrepreneurial skills necessary to physically move inputs into outputs. The high transaction costs make the industry inefficient. The industry/company's inconsistency caused by high transaction costs can be seen from the example of the research conducted by Yustika (2005). Yustika's research shows that the transaction costs of sugarcane farmers accounted for about 42 per cent of the total cost and the remaining 58 per cent of production costs. The decline of the national sugar industry is caused by institutional inefficiency, both at the institutional environment level and in institutional arrangements.

The emergence of transaction costs is at least owing to two things, namely, limited rationality and opportunistic behavior (Williamson, 2000). Humans have limitations in terms of receiving, storing, processing and retrieving information without making mistakes. The limitations of such individuals or groups will always be dealing with incomplete information or causing information uncertainty. Opportunistic behavior is the efforts made to gain profits by dishonest ways or practices in economic activities. However, if the benefits gained from competition based on the competitive advantage of an individual or group is not an opportunistic behavior. Innovative entrepreneurs will develop their social capital by building networks that provide external sources of information, support, finance and expertise that allow for mutual learning and help (Cope et al., 2007). Social capital can contribute to increasing happiness and prosperity (Dowling and Chin, 2007). The dimension of social capital, consisting of bonding, bridging and linking social capital, affects the empowerment of the poor (Babaei et al., 2012). This is enhanced by increasing the role of social capital. However, when morale decreases, productivity also decreases. High job morale, high work ethics, mutual trust and sharing of information are reflections of social capital. If social capital declines then business performance also decreases, and business activity is disrupted.

The results of Wu's (2008) research suggests that information sharing plays an important mediating role between the three dimensions of social capital (trust, network and continuous transactions) and enhanced corporate competitiveness. Strong social capital significantly affects intellectual capital, and social capital also positively and directly affects 
APJIE 13,1

empowerment (Maryam, 2017). Social capital can also affect an entrepreneur's entrepreneurship orientation. Social capital directly affects, positively and significantly, both entrepreneurship orientation and performance of industrial business actors (Gandhiadi et al., 2017). This indicates that the strengthening of social capital from industrial business actors can also strengthen the performance of the business undertaken. Variables based on cultural traits in each of the study areas are particularly important to be included in a study (Kozan et al., 2006). Chang et al. (2009) explains that social capital is needed to reduce the concerns about the difficulty of obtaining funding, thus that social capital and cultural capital as intangible capital can improve the company's financial performance. The strength of social capital can eliminate transaction costs (Sudrajat and Sudrajat, 2014) and Wimba, 2015). The occurrence of transaction cost efficiencies in SMEs as more access to information from government and business partners, coordinate each other to create regularity and negotiate to get agreement. Stronger social capital can improve transaction cost efficiency. Social capital can also be combined with other capital, such as financial capital, human capital and physical capital, to help community participation in improving welfare.

\section{Methodology}

The population in this research is all wood carving business in Bangli Regency, in all districts some 366 business units (Dinas Perindustrian dan Perdagangan Kabupaten Bangli, 2016). With the Slovin formula, using a 5 per cent error rate obtained a sample of 191 business units. Each business unit is represented by one craftsman as well as a business owner, in all existing sub-districts, namely, Bangli, Kintamani, Susut and Tembuku. The sampling method used is stratified random sampling based on the geographical area, because the business is homogeneous; thus, a certain number of samples will be taken from each district, bringing the total to 191 units of samples. To determine the sample unit to be interviewed from the craftsman, the method of accidental sampling is used. The data collection used in this research is through non-behavioral observation method and interviews (Jogiyanto, 2004). The interviews were conducted in a structured way to collect primary data from small wooden carving responders, using a pre-prepared list of questions.

This research uses three types of variables:

(1) exogenous variables;

(2) mediation variable (human capital [X2] and transaction costs [X3]); and

(3) endogenous variable (empowerment of small wooden craft industry [Y]).

Research variables are also divided into two groups, namely, variable formation (latent variables) - a variable formed through indicators observed in the real world. This formation variable is not measured directly but is formed through several dimensions observed through factor analysis put forward by Agung (2003). The variables formed in this research are human capital, social capital, transaction costs and empowerment of the woodcarving industry. Measurable variables are variables whose data should be searched through field research. The latent variable is measured by using respondent's perception of the understanding of the variable. Each instrument is assessed by the respondent, based on his/ her perception of the statement. Perceptions of respondents as measured by the instruments prepared in the form of statements are valid and reliable and are assessed using the Likert scale. The range of judgment starts from "strongly disagree" to "strongly agree" to the proposed statements: SS = strongly agree (5), S = agree (4), CS = quite agree (3), TS = disagree (2) and STS = strongly disagree (1). Empowering the small-scale wood carving industry (IKKUK) is the ability of IKKUK craftsmen to run their business continuously, as 
measured by using two indicators, namely, the ability to innovate and the ability to increase sales turnover. Social capital is measured using norms, trusts and networks. Human capital is the dimension of intellectual capital based on human knowledge and experience and will affect the value of the company by affecting the other elements. Human capital is measured using knowledge, skills and commitment. Transaction costs are the costs incurred to negotiate, measure and enforce exchanges. Transaction costs are measured using information costs, negotiation fees and coordination costs. The latent variables and indicator variables are shown in Table I.

This research uses quantitative approach, descriptive statistics and inferential analysis with path analysis technique. Inferential analysis was preceded by factor analysis techniques to obtain factor scores on each latent variable, followed by path analysis technique (Hair et al., 2010).

\section{Results and discussion}

\subsection{Characteristics of respondents}

Age, from an economic point of view, can give an idea of the condition of the respondents whether the research respondents are mostly classified as productive-age population or unproductive-age population. The 15-64 years age group forms the productive age population and 65 years and above forms the unproductive age population. The results of descriptive age analysis showed that there were four prominent age groups in this study, i.e. age group 30-34 years, 40-44 years old, $<30$ years and 35-39 years old, which covered more than 70 per cent of respondents. The age proportion of respondents in these age groups, is the peak age, i.e. the age that generally describes the highest level of productivity. In

\begin{tabular}{|c|c|c|c|}
\hline No. & Variable name & Indicator/instrument & \\
\hline 1 & Empowerment IKKUK (Y) & $\begin{array}{l}\text { Innovation } \\
\text { Sales total }\end{array}$ & \\
\hline \multirow[t]{9}{*}{2} & \multicolumn{2}{|l|}{ Social capital (X1): } & \\
\hline & Norm & $\begin{array}{l}\text { Hard work } \\
\text { Honest }\end{array}$ & \\
\hline & \multirow[t]{3}{*}{ Trust } & Maintaining product quality & \\
\hline & & Completed the product on time & \\
\hline & & Maintain consumer confidence & \\
\hline & \multirow[t]{4}{*}{ Network } & Make jejarung with consumers & \\
\hline & & Establish relationships with raw material suppliers & \\
\hline & & $\begin{array}{l}\text { Establish relationships with finance companies (LPD, banks, } \\
\text { cooperatives) }\end{array}$ & \\
\hline & & $\begin{array}{l}\text { Establish relationships with government (training, technical } \\
\text { assistance, etc.) }\end{array}$ & \\
\hline \multirow[t]{3}{*}{3} & \multirow[t]{3}{*}{ Human capital (X2) } & Knowledge & \\
\hline & & Skills & \\
\hline & & Commitment & \\
\hline \multirow[t]{7}{*}{4} & Transaction cost (X3): & & \\
\hline & \multirow{2}{*}{ 1) The cost of information } & Minimize the cost of seeking information & \\
\hline & & Minimize the cost of finding information about capital & \\
\hline & \multirow[t]{2}{*}{ 2) Cost negotiation } & Minimize negotiation costs of the products sold & \\
\hline & & Minimize the cost of bargaining for buying raw materials & Table I. \\
\hline & \multirow[t]{2}{*}{ 3) Coordination costs } & Observe the cost of coordinating with raw material suppliers & Variables and \\
\hline & & $\begin{array}{l}\text { Pay close attention to the costs incurred in coordinating with buyers } \\
\text { for goods ordered or purchased if delivered to the place of purchase }\end{array}$ & $\begin{array}{r}\text { indicators/research } \\
\text { instruments }\end{array}$ \\
\hline
\end{tabular}


APJIE 13,1

subsequent age groups, the level of productivity began to decline and continued to fall with the age of respondents. Distribution of age groups as described above, demographically, also can be known that in general respondent of this research is adult.

Characteristics of respondents by education are derived from information about the highest level of education completed. The level of education received by the respondents in this study varies considerably. The lowest level of education is incomplete primary school and the highest education is graduation from a university. The most prominent educational level of respondents is primary school graduation, which is indicated by approximately 39.3 per cent. Nevertheless, educated respondents who graduated from junior high school to senior high school were the most dominant, indicated by 56.3 per cent.

\subsection{Descriptive analysis of latent variables}

The latent variable of empowerment is proxied by using two research instruments: innovation and increasing sales turnover. Most participants responded agreeably to the proposed statement, indicated by 99.4 per cent. Only a small percentage of respondents, i.e. 0.6 per cent who perceive quite agree to the proposed statement. Based on the percentage of respondents' answers, it can be concluded that the craftsmen continue to work to improve empowerment as a wood carving pengerajin by trying to improve both innovation and increase sales turnover.

Social capital as an exogenous variable is proxied using several indicators of norm, trust and network. The results of descriptive analysis of latent variables of social capital are downgraded again into several instruments. Associated with the norm of social capital, the majority of respondents gave the perception of agree or strongly agree to the proposed statement. Approximately 86 per cent of respondents strongly agree that if the business is done seriously, it will fetch satisfactory results, and about 24 per cent agree with the statement. Likewise, the respondent's perception of the norm shown by the existence of honesty in the activity as a craftsman is a strong social capital that must be maintained. Honesty responded well to very well by a large percentage of respondents is about 99.5 per cent.

Indicator of social capital of trust, perceived by respondents, varied enough on alternative answers agree to strongly agree, shown by 39 per cent who said they strongly agree and 61 per cent who agree, related to the resulting product is quality. Respondents' perceptions related to the assertion that to maintain consumer confidence, the products are completed on time, shown by approximately 83 per cent of respondents agreed to strongly agree. Only a small proportion of respondents expressed disagreement (8 per cent). This indicates that there are respondents who sometimes do not timely in accordance with the promise to complete orders from consumers. Associated with consumer confidence that the material used to produce the resulting product is in accordance with the agreement, shown by about 97 per cent of respondents.

Respondents establish relationships with other parties, indicating a network that is formed in making transactions. In addition to establishing relationships with fellow craftsmen, respondents also have relationships with customers, raw material suppliers and finance/funding companies such as banks and village credit institutions (LPDs) and establish relationships with the government. The results of the analysis show that in addition to establishing relationships with fellow craftsmen, the respondents established a relationship with consumers indicated by approximately 96 per cent agreed to strongly agree on the statement two. Approximately 93 per cent of respondents stated that it is important to establish relationships with raw material suppliers, about 78 per cent of them 
stated the importance of establishing relationships with finance companies, which are perceived to agree strongly.

In relation to networks established with the government, particularly in terms of training, technical assistance and others, only a small percentage of respondents agreed, and most respondents stated that they disagreed (90 per cent). This indicates that most of the respondents sampled in this study have not been helped directly by the government's role in providing training and technical assistance. For the future, government programs to help the craftsmen, especially wood carving, in terms of providing training and technical assistance should be improved because the craftsmen really need the role of the government to improve the empowerment of handicraft business.

The role of human resources in this study was derived by using research instruments, namely, knowledge, skills and commitment as a craftsman. All participants responded agreed or strongly agreed that knowledge of the small woodcraft industry is important (100 per cent). Most respondents agreed or strongly agreed that the essential skills to produce this business were shown by about 82 per cent, and only about 18 per cent responded adequately. Likewise, having a commitment as a woodcarving craftsman is crucial for maintaining the sustainability of the undertakings undertaken by 97 per cent of respondents who agree to agree strongly, only a small proportion responds sufficiently of about 3 per cent.

The transaction cost variable in this study is proxied by using three indicators, namely, information cost, negotiation cost and coordination cost. Each transaction cost indicator is downgraded into several research instruments. The cost of information includes the cost of information to search for raw materials and information costs to obtain a capital loan. Majority of respondents agreed that cost of seeking information to obtain raw materials should be minimized. However, some other respondents disagreed with the statement (39 per cent). After further searching, they never pay a fee to get information related to raw materials. Information related to raw materials needed is often obtained from fellow craftsmen, so there is no need to pay for the raw materials. Most respondents also disagreed with the proposed statement regarding the cost of information to obtain a capital loan (75 per cent). After further tracing, it turns out they did not ever take a capital loan from a financial institution, so there was no need to incur costs associated with information to get a loan capital. Transaction costs associated with negotiations are derived using two instruments: bargaining fees on products sold and bargaining for raw materials. Most respondents did not agree with the statements related to negotiation costs on products sold or the cost of negotiations to obtain raw materials (65 per cent and 68 per cent, respectively). This indicates that most of the respondents did not incur negotiation costs to sell their handicraft products or to obtain raw materials. Coordination costs were also reduced to two instruments, namely, coordination costs to buy raw materials and coordination costs to sell products to buyers so that costs that appear can be observed. Most of the respondents agreed or strongly agreed to observe this coordination cost, shown by about 85 per cent and 99.5 per cent that coordination to obtain raw materials and sell the products produced is very important to be done so that the costs can be pressed out.

\subsection{Validity and reliability instruments}

The data were collected using research instruments. Then, these instruments were tested for validity and reliability (Table II).

Validity testing was carried out to find out if the instruments in the data collection on the respondents' perception were appropriate to be used as data collection tools. Validity testing uses score correlation on each instrument value against the total score value. An instrument 


\begin{tabular}{|c|c|c|c|c|}
\hline \multirow{5}{*}{$\begin{array}{l}\text { APJIE } \\
13,1\end{array}$} & Indicator & Item & Validity (total Pearson's correlation) & Reliability (Cronbach's alpha) \\
\hline & Empowerment/Y & E11 & 0.695 & 0.858 \\
\hline & & E22 & 0.875 & \\
\hline & Social capital/ $\mathrm{X}_{1}$ (norm) & SC11 & 0.688 & 0.905 \\
\hline & & $\mathrm{SC} 12$ & 0.712 & \\
\hline \multirow{10}{*}{130} & Social capital/ $\mathrm{X}_{1}$ (trust) & $\mathrm{SC} 21$ & 0.544 & 0.694 \\
\hline & & $\mathrm{SC} 22$ & 0.647 & \\
\hline & & $\mathrm{SC} 23$ & 0.614 & \\
\hline & Social capital/ $\mathrm{X}_{1}$ (network) & SC31 & 0.427 & 0.684 \\
\hline & & SC32 & 0.553 & \\
\hline & & SC33 & 0.773 & \\
\hline & & $\mathrm{SC} 34$ & 0.608 & \\
\hline & Human capital/ $\mathrm{X}_{2}$ & $\mathrm{HCl}$ & 0.686 & 0.803 \\
\hline & & $\mathrm{HC} 2$ & 0.905 & \\
\hline & & $\mathrm{HC} 3$ & 0.641 & \\
\hline \multirow{6}{*}{$\begin{array}{l}\text { Table II. } \\
\text { Results of validity } \\
\text { and reliability testing } \\
\text { of research } \\
\text { instruments }\end{array}$} & Total cost $/ \mathrm{X}_{3}$ (information) & TC11 & 0.530 & 0.745 \\
\hline & & $\mathrm{TC} 12$ & 0.412 & \\
\hline & Total cost $/ \mathrm{X}_{3}$ (negotiation) & TC21 & 0.932 & 0.774 \\
\hline & & $\mathrm{TC} 22$ & 0.915 & \\
\hline & Total cost $/ \mathrm{X}_{3}$ (coordination) & TC31 & 0.488 & 0.730 \\
\hline & & TC32 & 0.706 & \\
\hline
\end{tabular}

is said to be valid if the correlation value has reached above 0.3 . From the calculation results, it can be seen that the correlation value has reached above 0.3 .

Reliability testing of research instruments was carried out by calculating the Cronbach's alpha value. The instrument is said to be reliable if the Cronbach's alpha reaches above 0.6. Meanwhile, the Cronbach's alpha value in the calculation has shown the value to be greater than 0.6. Thus, the instruments used in this research are reliable.

\subsection{Inferential analysis}

Path Analysis The influence of social capital on human capital is shown as Table III. The result of the analysis (Table III) gives the regression equation $\mathrm{X} 2=0.354 \mathrm{X} 1$, indicating that social capital has a positive and significant influence on human capital. This is shown by the value of $t$ arithmetic 5.206 is greater than $t$ table I.64 or sig value 0.000 smaller than $\alpha=5$ per cent. Thus, it can be said that the higher the social capital, the higher the role of human capital. Strong social capital demonstrated by norms, beliefs and networks formed with fellow craftsmen, consumers, raw material suppliers, funding agencies and with governments can enhance the role of human capital. The higher the social capital, the higher the desire to increase knowledge, skills and commitment that reflect the role of human capital. Characteristics of human capital, such as training programs, experience,

Results of direct influence from the model

\begin{tabular}{lccc}
\hline Relationship & Coefficient & $t$ & Significance \\
\hline $\mathrm{SC}\left(\mathrm{X}_{1}\right) \rightarrow \mathrm{HC}\left(\mathrm{X}_{2}\right)$ & 0.354 & 5.206 & 0.000 \\
$\mathrm{SC}\left(\mathrm{X}_{1}\right) \rightarrow$ TC $\left(\mathrm{X}_{3}\right)$ & 0.148 & 2.060 & 0.041 \\
$\mathrm{SC}\left(\mathrm{X}_{1}\right) \rightarrow$ EMPW $(\mathrm{Y})$ & 0.152 & 2.032 & 0.044 \\
$\mathrm{HC}\left(\mathrm{X}_{2}\right) \rightarrow$ EMPW $(\mathrm{Y})$ & 0.389 & 3.272 & 0.001 \\
$\mathrm{TC}\left(\mathrm{X}_{3}\right) \rightarrow$ EMPW $(\mathrm{Y})$ & -0.171 & -1.522 & 0.130 \\
\hline
\end{tabular}


competence, recruitment, mentoring, learning programs and individual potentials (Brinker, 2000), ability and potential, motivation and commitment, innovation and learning (Mayo, 2001) dimension of human capital. This research is supported by Maryam (2017), who states that social capital has a significant effect on human capital.

The result of analysis shows that social capital has a positive and significant effect on transaction cost. This means that the higher the social capital, the further the transaction costs can be reduced. The positive influence indicates that when the social capital of craftsmen is strong, the effort to minimize transaction costs arising from economic activity handicraft can be kept as low as possible. The higher the respondent's perception of the social capital indicator, the higher the effort to reduce the transaction costs that may arise in any economic transaction. The results of the analysis are shown in Table III.

Based on the analysis shown in Table III, we can construct the following structural equation: $\mathrm{X} 3=0.148 \mathrm{X} 1$. The analysis results show $t$ count value of 2.060 greater than 1.64 or significant value 0.041 smaller than tingkiat $\alpha=5$ per cent used in this study. Craftsmen who sell their products to consumers and who make transactions by buying raw materials from suppliers certainly based on mutual trust in the product or raw materials are transacted. Transaction costs measured using the cost of obtaining information, the cost of negotiating and the cost of coordinating, if it should be excluded, can be minimized if based on trust, norms and the nets formed in the transaction. North and Wallis (1994), Mburu (2002) and Yustika (2013) suggest that transaction costs arise because of a transaction. Thus, transaction costs can be minimized so that the transaction becomes more efficient. Social capital can minimize transaction costs, according to Dyer and Singh (1998), Sudrajat and Sudrajat (2014) and Wimba (2015).

The latent variable The empowerment of small wooden craft industry is measured by using two instruments: innovation and sales turnover. If the craftsmen are able to innovate and increase the sales turnover, it can be said that the entrepreneur has been able to show the empowerment of the business done. The analysis results are shown in Table III.

Social capital and human capital are partially significant for the empowerment of the small wooden craft industry, with standardized coefficient values of 0.152 and 0.389 , respectively. The $t$-values of each, 2.032 and 3.372, are bigger than $t$ table I.64, or the significance value of 0.44 and 0.001 is smaller than the value of $\alpha=5$ per cent used in this study. However, transaction costs have no significant effect on empowerment. It can be explained that most of the craftsmen did not pay much attention to the appearance of the transaction costs because most of them did not feel the cost of the transaction. This can be supported by descriptive analysis, as described previously. The majority of respondents, about 76 per cent, did not feel the need to spend on information, especially to get information related to efforts for obtaining funding from related institutions. Also, the craftsmen felt that they did not incur negotiation costs to sell products to consumers or to obtain raw materials (65 and 68 per cent).

The results of the analysis (Table III) can be explained that the better social capital the farmer will be more empowered, as well as the better human capital the more empowering farmer small industry of wood carving craft under study. The social capital shown by the existence of trust, norm, honesty and the formation of a strong network between craftsmen, raw material suppliers and consumers can improve the ability of craftsmen to innovate and increase sales turnover. The higher the knowledge and skills and the more committed as the craftsman then the more empowered. This is also supported by the level of formal education that is in the criteria of junior high, indicated by most respondents (57 per cent). This condition can also support the ability of craftsmen to increase the role of human resources to improve the empowerment kerajian business that has been occupied for this. The results of 
APJIE

13,1

\section{2}

Figure 1.

Relationship among $\mathrm{SC}, \mathrm{HC}$ and EMPW this study are also supported by previous research studies, which were used as reference (Kherallah and Kristen, 2001; Sukoco and Hardi, 2013; Collins and Hitt, 2006; Wu, 2008; Mushrel, 2014; Majee, 2015; Gandhiadi et al., 2017; Astawa et al., 2015).

The results of the analysis are shown in Table III. Table III can be illustrated that the indirect effect of social capital variable on empowerment through human capital variable and transaction costs. The results of the analysis show that human capital partially mediates the influence of social capital on empowerment through human capital. It can be explained that social capital has a significant effect on human capital, human capital also has a significant effect on empowerment and so also, social capital directly has a significant effect on empowerment. This research is supported by the research by Cope et al. (2007), Dowling and Chin (2007); and Babaei et al. (2012) that social capital affects both empowerment and welfare. This explanation is shown in Figure 1.

The transaction cost variable is not a variable mediating the influence of social capital on empowerment. This can be illustrated as Tables III and IV, that social capital has a significant effect on transaction costs, social capital has a significant effect on empowerment, but transaction cost has no significant effect on empowerment; hence, it can be concluded that transaction cost is not a variable mediating the influence of social capital on the empowerment of the small wood craft industry studied. The link between these variables is shown in Figure 2.

\section{Conclusions and suggestions}

Based on the analysis described in the previous chapter, several conclusions can be drawn:

- Social capital has a positive and significant effect on human resources in the small woodcraft industry in Bangli Regency. The stronger the role of social capital, the ever-increasing the role of human resources.

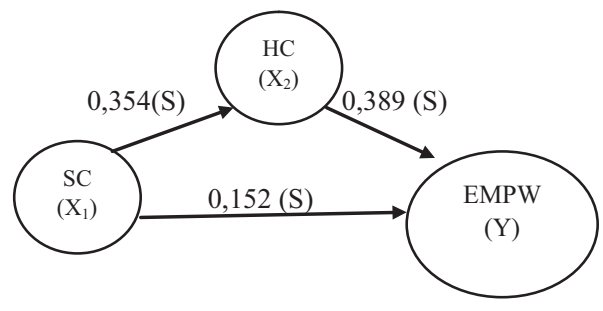

\section{Table IV.}

Results of indirect influence from the model
Calculation
Coefficient

$\mathrm{SC}\left(\mathrm{X}_{1}\right) \rightarrow \mathrm{HC}\left(\mathrm{X}_{2}\right) \rightarrow \mathrm{EMPW}(\mathrm{Y}) \mathrm{SC}\left(\mathrm{X}_{1}\right) \rightarrow \mathrm{HC}\left(\mathrm{X}_{2}\right) \times \mathrm{HC}\left(\mathrm{X}_{2}\right) \rightarrow \mathrm{EMPW}(\mathrm{Y}) \quad 0.354 \times 0.389=0.137706$ $\mathrm{SC}\left(\mathrm{X}_{1}\right) \rightarrow \mathrm{TC}\left(\mathrm{X}_{3}\right) \rightarrow \mathrm{EMPW}(\mathrm{Y}) \mathrm{SC}\left(\mathrm{X}_{1}\right) \rightarrow \mathrm{TC}\left(\mathrm{X}_{3}\right) \times \mathrm{TC}\left(\mathrm{X}_{3}\right) \rightarrow \mathrm{EMPW}(\mathrm{Y}) 0.148 \times-0.171=-0.025308$
Figure 2.

Relationship among $\mathrm{SC}, \mathrm{TC}$ and EMPW

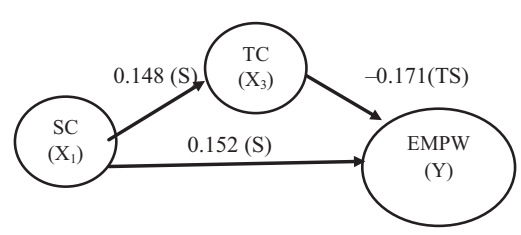


- Social capital is positive and significant for transaction cost in the small woodcraft industry in Bangli Regency. The stronger the social capital, the greater the ability of the craftsmen to reduce transaction costs.

- Social capital and human resources have a positive and significant effect, whereas transaction cost has no significant positive effect, on empowering the small woodcraft industry in Bangli Regency.

- Human resources partially mediate the influence of social capital on empowering the small woodcraft industry in Bangli Regency.

Stronger social capital can increase the role of human capital to improve the empowerment of the small woodcraft industry in Bangli Regency. The transaction cost does not act as a variable mediating the influence of social capital on empowering the small woodcraft industry in Bangli Regency.

Based on these results, it can be seen that empowerment of the woodcraft small-scale industry in Bangli Regency is affected by the social capital and human resources. Meanwhile, social capital influences human resources and transaction fee. Thus, the community and government should improve the human resources and its social capital to improve the empowerment of the woodcraft small-scale industry. The craftsmen need to further improve their skills to increase the role of the resources they possess. The role of the government needs to be improved, especially in providing training and technical assistance to better the ability to innovate so as to enhance the empowerment of the small woodcraft industry in Bangli Regency. Maintaining trust, honesty and mutual cooperation to suppress the possibility of transaction costs.

This research can still be further developed because it has are a few limitations:

- The research location was only Bangli Regency in Bali, Indonesia.

- The path analysis was tested using the multiple linear regression analysis.

Further research can use software, specifically for path analysis, or other more complex analyses.

\section{References}

Abedullah, S.K. and Mushtaq, K. (2007), "Analysis of technical efficiency of rice production in Punjab (Pakistan), implications for future investment strategies", Pakistan Economic and Social Review, Vol. 45 No. 2, pp. 231-244.

Adler, P.S. and Kwon, S.W. (2000), "Social capital: the good, the bad, and the ugly", in Lesser, E.I. (Ed.), Knowledge and Social Capital: Foundations and Applications, Butterworth-Heinemann, Woburn, MA, pp. 89-115.

Adler, P.S. and Kwon, S.-W. (2002), "Social capital: prospects for a new concept", Academy of Management Review, Vol. 27 No. 1, pp. 17-40.

Adojutelegan, O.T., Adereti, F.O., Makanju, T.S. and Olorunfemi, O.D. (2015), "Analisys of factors affecting watermelon production in Ekiti state, Nigeria", Science, Technology and Arts Research Journal, Vol. 4 No. 2, pp. 324-329.

Agung, I.N. (2003), Manajemen Penulisan Skripsi, Tesis Dan Disertasi: Kiat-Kiat Untuk Persingkat Waktu Penulisan Karya Imiah Yang Bermutu, UI Press, Jakarta.

Arsyad, L. (2001), Peramalan Bisnis, BPFE, Yogyakarta.

Astawa, I.P., Sudika, I.P. and Yuliarmi, N.N. (2015), "Intangible capital and leverage to improve financial performance of LPG agents in Bali", Procedia-Social and Behavioral Sciences, Vol. 211, pp. 149-156. 
APJIE 13,1

Babaei, H., Ahmad, N. and Gill, S.S. (2012), "Bonding, bridging, and linking social capital and empowerment among squatter settlements in Tehran, Iran”, World Applied Sciences Journal, Vol. 17 No. 1, pp. 119-126.

Bowles, S. and Gintis, H. (2002), "Social capital and community governance", The Economic Journal, Vol. 112 No. 483, pp. F419-F436.

Brinker, B. (2000), "Intelectual capital: tomorrows asset, today's challenge”, www.cpavision.org/vision/ wpaperols.cfm

Chang, E.P., Memili, E., Chrisman, J.J., Kellermanns, F.W. and Chua, J.H. (2009), "Family social Capital, venture preparedness, and start-up decisions: a study of hispanic entrepreneurs in new England”, Family Business Review, Vol. 22 No. 3, pp. 279-292.

Coleman, J.S. (1988), "Social capital in the creation of human capital", The American Journal of Sociology, Vol. 94, pp. S95-S120. Supplement: Organizations and Institution: Sociological and Economic Approaches to the Analysis of Social Structure.

Coleman, J.S. (1990), Foundations of Social Theory, Belknap Press, Cambridge, MA.

Collins, J.D. and Hitt, M.A. (2006), "Leveraging tacit knowledge in alliances: the importance of using relational capabilities to build and leverage relational Capital", Journal of Engineering and Technology Management, Vol. 23 No. 3, pp. 147-167.

Cope, J., Jack, S. and Rose, M.B. (2007), "Social capital and entrepreneurship: an introduction", International Small Business Journal: Researching Entrepreneurship, Vol. 25 No. 3, pp. 213-219. Vol No

Cox, E. (1995), A Truly Civil Society, ABC Bokks, Sydney.

Dinas Perindustrian dan Perdagangan Kabupaten Bangli (2016), Suparmoko, M. 2002. Ekonomi Publik, Untuk Keuangan dan Pembangunan Daerah. Andi. Yogyakarta.

Dowling, J.M. and Chin, F.Y. (2007), Modern Development in Behavioral Economics, Social Science Perspective on Choice and Decision Making, World Scientific Publishing, Singapore.

Dyer, J.H. and Singh, H. (1998), "The relational view: cooperative strategy and sources of interorganizational competitive advantage", Academy of Management Review, Vol. 23 No. 4, pp. 660-679.

Friedmann, J. (1992), Empowerment: the Politics of Alternative Development, Blackwell, Ontario.

Fukuyama, F. (2000), Social Capital and Civil Society (No. 0-74), International Monetary Fund, Washington, DC.

Gandhiadi, G.K., Sudibia, I.K., Suyana Utama, I.M. and Saskara, I.A.N. (2017), "The influence of social capital on subjective wellbeing: a structural model for the weaving industry in Bali province of Indonesia", International Journal of Economics Commerce and Management, Vol. 5 No. 6.

Hair, J.F., Jr, Black, W.C., Babin, B.J. and Anderson, R.E. (2010), Multivariate Data Analysis, A Global Perspective, Seventh Edition, Pearson, London.

Hasbullah, J. (2006), Social Capital (Menuju Keunggulan Budaya Manusia Indonesia), MR United Press, Jakarta.

Hendratmoko, C. and Marsudi, H. (2010), “Dinamika sosial ekonomi”, Edisi Mei, Vol. 6 No. 1, pp. 1-17.

Ho, T.Q., Yanagida, J.F. and Illukpitiya, P. (2014), "Factors affecting technical efficiency of smallholder coffee farming in the krong ana watershed, Vietnam", Asian Journal of Agricultural Extension, Economics and Sociology, Vol. 3 No. 1, pp. 37-44.

Jogiyanto, H.M. (2004), Metodologi Penelitian Bisnis: Salah Kaprah Dan Pengalaman-Pengalaman, BPFE, Yogyakarta.

Kherallah, M. and Kristen, J. (2001), "The new institutional economics: applicatioan for agricultural policy reseacrh in developing countries", MDSS Discusstion Paper No. 41, IFRI, Washington, DC.

Kozan, M.K., Öksoy, D. and Özsoy, O. (2006), "Growth plans of small businesses in Turkey: individual and environmental influences", Journal of Small Business Management, Vol. 44 No. 1, pp. 114-129. 
Li, X. and Liu, D. (2015), "Urbanization and grain production efficiency”, Asian Agricultural Research, Vol. 7 No. 7, pp. $75-80$.

Lino, B. and Vella, M. (2014), Technological Advance, The Labour Share of National Income and Income Inequality in the EU, Department of Economics, University of Malta, Valletta.

Lubis, R.F. and Saputra, P.M.A. (2015), "The middle-income trap: is there a way out for asian countries?", Journal of Indonesian Economy and Business, Vol. 30 No. 3, pp. 273-287.

Luttrell, C., Quiroz, S., Scruton, C. and Bird, K. (2009), Understanding and Operationalising Empowerment, Overseas Development Institute, London.

Majee, W. (2015), "Cooperative, the brewing post for social capotal an exploration of social capital creation in a Worker-Owned homecare cooperative" (accessed 20 November 2016).

Maryam, D. (2017), "Pengaruh modal sosial dan modal intelektual terhadap keberdayaan koperasi dan kesejahteran manusia di kota denpasar", Disertasi, Program Pascasarjana Fakultas Ekonomi dan Bisnis Universitas Udayana, Denpasar.

Mayo, A. (2001), The Human Value of the Enterprise - Valuing People as Assets - Monitoring, Measuring, Managing, Brealey Publishing, London.

Mburu, N. (2002), "The Proliferation of guns and rustling in karamoja and Turkana districts: the case for appropriate disarmament strategies", Journal of Peace, Conflict and Development, Vol. 2 No. 2, p. 10.

Miranda, A.T. and Miranda, J.L.F. (2018), "Status and conditions of smalland medium-sized enterprises as predictors in empowering rural communities in Samar Island, Philippines", Asia Pacific Journal of Innovation and Entrepreneurship, Vol. 12 No. 1, pp. 105-119.

Mushrel, A.M. (2014), "The moderator role of organizatioan culture between intelectual capital and business performance: an empirical study an iraqi industry", Net Journal of Social Science, Vol. 2 No. 3, pp. 82-92.

Ng'ombe, J. and Kalinda, T. (2015), "A stochastic frontier analysis of technical efficiency of maize production under minimum tillage in Zambia”, Sustainable Agriculture Research, Vol. 4 No. 2, p. 31.

North, D.C. and Wallis, J.J. (1994), "Integrating institutional change and technical change in economic history a transaction cost approach", Journal of Institutional and Theoretical Economics (IITE)/ Zeitschrift für die gesamte Staatswissenschaft, Vol. 150 No. 4, pp. 609-624.

Nort, R.B., Campbell, J.N., James, C.S., Walker, M.K.C., Wang, H., Piantadosi, S. and Long, D.M. (1991), "Failed back surgery syndrome: 5-year follow-up in 102 patients undergoing repeat operation", Journal of Neurosurgery, Vol. 28, pp. 685-691.

Park, Y.J. and Park, Y.W. (2018), "Spinoffs versus non-spinoff entrepreneurs: exploring postbubble Japan's entrepreneurial ecosystem", Asia Pacific Journal of Innovation and Entrepreneurship, Vol. 12 No. 2, pp. 146-164.

Portes, A. (1998), "Social capital: its origins and applications in modern sociology", Annual Review of Sociology, Vol. 24 No. 1, p. 24.

Purnomo, D. and Devi, I. (2008), "Analisis peranan sektor industri terhadap perekonomian Jawa Tengah Tahun 2000 dan tahun 2004 (Analisis input output)", Jurnal Ekonomi Pembangungan, Surakarta, Vol. 1.

Ramli, H.N. (2010), Keberdayaan UKM, Kementrian Negara Koperasi dan Usaha Kecil dan Menengah Republik Indonesia, Jakarta, available at: www.google.com

Roebyantho, H. and Padmiati, E. (2007), "Pemberdayaan jaringan pranata sosial dalam penguatan ketahanan sosial masyarakat Di provinsi sumatera selatan", Jurnal Penelitian Dan Pengembangan Kesejahteraan Sosial, Vol. 12 No. 3, pp. 33-44, available at: www.google.com

Salazar-Acosta, M. (2006), "Innovation systems based indicators: Emphasis on human Capital and ICT adoption", What Indicators for Science, Technology and Innovation Policies in the 21st Century Conference in Statistics Canada, Simon Fraser University, Ottawa.
Wood carving handicraft 
APJIE 13,1

Shaikh, S. (2012), "Human resource information system (HRIS) designing needs for business application”, ZENITH International Journal of Business Economics and Management Research, Vol. 2 No. 1, pp. 256-264.

Sippola, A. (2007), "Developing culturally diverse organizations: a participative and empowermentbased method", Women in Management Review, Vol. 22 No. 4, pp. 253-273.

Subandi, S. (2007), "Kedudukan dan kiprah koperasi dalam mendukung pemberdayaan UMKM", Jurnal Pengkajian Koperasi Dan UKM, Vol. 1.

Sudrajat, M.S. and Sudrajat, J. (2014), "Pengembangan sistem informasi kredit usaha rakyat Di PT. BPR nusamba tanjungsari”, Jurnal Computech and Bisnis, Vol. 8 No. 2, pp. 80-91.

Suharto, E. (2014), Membangun Masyarakat Memberdayakan Rakyat Kajian Strategis Pembangunan Kesejahteraan Sosial Dan Pekerja Sosial, Refika Aditama, Bandung.

Sukoco, B. and Hardi, M. (2013), "Pengaruh modal sosial pada perilaku berbagi pengetahuan dan kinerja: Studi kasus di pemasok komponen otomotif astra grup”, Jurnal Manajemen Teknologi, Vol. 12 No. 3.

Sumodiningrat, G. (2000), Pembangunan Ekonomi Melalui Pengembangan Pertanian, Bina Rena Pariwara, Jakarta.

Suparmoko, M. (2002), "Ekonomi publik untuk keuangan dan pembangunan daerah, andi”.

Tran, A.T.P. and Korflesch, H.V. (2016), "A conceptual model of social entrepreneurial intention based on the social cognitive career theory", Asia Pacific Journal of Innovation and Entrepreneurship, Vol. 10 No. 1, pp. 17-38.

Voydanoff, P. (2001), "Conceptualizing community in the context of work and family community", Work and Family, Vol. 4 No. 2, pp. 133-156.

Williamson, O.E. (2000), "The new institutional economics; taking stock, looking ahead", Journal of Economics Literature V, Vol. 38 No. 3, pp. 595-613.

Wimba, I.G.A. (2015), "Pengaruh modal sosial terhadap orientasi kewirausahaan dan biaya transaksi untuk meningkatkan kinerja usaha pada UKM kerajinan kayu di provinsi Bali”, Disertasi, Pascasarjana Universitas Udayana.

Woolcock, M. (1998), "Social capital and economic development: towards a theoritical synthesis and policy framework", Theory and Society, Vol. 27 No. 2, pp. 151-208.

Wu, W.-P. (2008), "Dimensions of social capital and firm competitiveness improvement: the mediating role of information sharing", Journal of Management Studies, Vol. 45 No. 1, pp. 122-146.

Yeo, C.S. and Saboori-Deilami, V. (2017), "Strategic challenges of outsourcing innovation in global market", Asia Pacific Journal of Innovation and Entrepreneurship, Vol. 11 No. 1, pp. 5-16.

Yuliarmi, N.N., Suman, A., Kiptiyah, S.M. and Yustika, A.E. (2012), "The role of government, Traditional instiyution, and social capital, for empowering small and medium industries", Journal of Economics, Business, Accountancy Ventura, Vol. 15 No. 2, pp. 205-218.

Yustika, A.E. (2005), "Problems of the Indonesia sugar industri: an institutional economics perspective", Jurnal Ekonomi Dan Bisnis Indonesia, Vol. 20 No. 4.

Yustika, A.E. (2013), Ekonomi Kelembagaan, Definisi, Teori Dan Strategi, Banyumedia Publishing, Malang.

For instructions on how to order reprints of this article, please visit our website:

www.emeraldgrouppublishing.com/licensing/reprints.htm

Or contact us for further details: permissions@emeraldinsight.com 